\title{
The Effectiveness of E-marketing to Strengthen the Product Quality Customer Trust and Commitment with Organizations. A Systematic Literature Review from the Last Two Decades
}

\author{
Maha Abbas Alazwari \\ 1.College of Business, Umm Al-Qura University, 21955, Makkah, Saudi Arabia \\ 2.College of Education, Niagara University, 14109, Niagara, United States \\ mamazwari@uqu.edu.sa \& malazwari@mail.niagara.edu
}

\begin{abstract}
Our daily lives have become increasingly digitized. It is changing the way consumers and businesses engage in the conventional sense. Consumer behavior is changing due to digitization, mainly social media, with significant implications for businesses, goods, and brands. This study evaluates the determine of consumer perceived value influences the relationship between customer satisfaction and loyalty. Another objective of this study is to evaluate the quality of e-services that influence customer pleasure, leading to customer loyalty. For this purpose, we used the Scopus database for the data extraction; the PRISMA statement 2015 inclusion and exclusion framework is used to select data. E-marketing and customer satisfaction keywords are used in the search bar, and 1725 results are shown and follow the screening process. The final 51 articles and reviews are used for the systematic literature review after the detailed screening process. The results have classified the literature into segment, focus, and findings. The study's findings demonstrate that e-marketing is significantly enhancing customer satisfaction and brand loyalty.
\end{abstract}

Keywords: The Effectiveness of E-marketing, Strengthen the Product Quality Customer Trust and Commitment with Organizations.

DOI: $10.7176 / \mathrm{EJBM} / 13-18-01$

Publication date:September $30^{\text {th }} 2021$

\section{Introduction}

Our daily lives have become increasingly digitized. It is changing the way consumers and businesses engage in the conventional sense. Consumer behavior is changing due to digitization, mainly social media, with significant implications for businesses, goods, and brands. Consumers are spending more time online and on social media than ever before. They utilize online services for browsing, saving, and playing music, e-mailing, accessing Facebook, Twitter, and applications using various linked devices such as smartphones, tablets, and laptops, changing how people use the internet. "If a firm cannot be discovered on Google, it does not exist," goes the proverb. Customers are notoriously tough to satisfy or persuade with e-marketing alone. Many customers are hesitant to buy because they are unsure of the product's quality or the company's devotion to its claims of secrecy while simultaneously offering a high-quality product (Hellman \& Thompson, 2017). As a result, many consumers like to read much information first, especially if there have been past customer experiences. Reading their comments about the product makes them feel more at ease, which speeds up the process of making a final purchase choice (Sreedevi et al., 2017).

Some businesses provide their client's free samples of their items so that they may try them out before buying them. That enhances the consumer's trust and commitment to the firm, resulting in increased sales volume and customer loyalty. That also spreads awareness and promotes customer confidence in a faster and easier way. E-service companies face significant difficulty in gaining customer loyalty. According to (Raza et al., 2021), loyalty is defined as a customer's positive opinion regarding an e-service provider's online website, promoting repeat purchasing behavior. Customer loyalty breeds customer trust, which helps e-service providers establish long-term relationships with clients while also generating revenues.

However, the importance of an economic situation in e-services still debates the magnitude of service quality's effect on crucial variables such as marketing and engagement impulsive buying and the theoretical model of service quality and its antecedents and implications. Several studies have examined the history of excellent online services in navigation, visual appeal, speed, access, content customization, dependability, and satisfaction and loyalty. These studies have significantly improved our understanding of internet services (Savage et al., 2013a). Satisfaction, value, change resistance, affect, brand trust, and brand equity have all been related to customer loyalty (including behavioral and attitudinal loyalty). There are two forms of loyalty: attitude and behavior. Repurchase behavior prompted by a good attitude about things is called attitudinal loyalty (Qureshi, Khan, Qayyum, et al., 2020). In other words, the conative phase is concerned with the impulse to act. Attitudinal loyalty (behavioral intention) refers to a commitment to repurchase or patronize a product. Behavioral loyalty refers to the act of repurchasing or re-patronizing products (Khan, Qureshi, Mustapha, Irum, 
et al., 2020).

According to the findings of (Khan, Qureshi, Mustapha, Harasis, et al., 2020), consumers today expect businesses that engage with them in a variety of ways, providing the most incredible experience while also demonstrating that they have the same interests. They want to buy from firms that know who they are, what they need, and how to solve their problems. At the same time, a tailored experience might assist; additional online tools can utilize to develop customer trust and connections.

According to most researchers (Bt Jaafar et al., 2020), loyalty is one of the most critical aspects for a company to obtain a competitive advantage and flourish in a competitive market. Users can develop loyalty if they are pleased with their operators based on previous experiences and if switching is difficult. It has been discovered that attachment stage contentment, switching barriers, and loyalty in the experience. The goal of this study is to see if consumer perceptions of value have an impact on the link between customer happiness and loyalty. Another goal of this study is to determine whether the quality of e-services impacts consumer satisfaction, which leads to customer loyalty.

\section{Methodology}

A literature review is a study that examines current literature on a topic to help construct theories, fill knowledge gaps, and suggest areas where additional research is needed. This research aims to systematically examine product quality, consumer trust, and previous business commitment to e-marketing. To that end, a quantitative review based on bibliometric analysis was conducted, as well as a qualitative review based on a systematic review, which primarily consists of four steps of literature research, quality assessment, eligibility and inclusion criteria, and studies included in a qualitative synthesis of relevant studies (Figure 1). As opposed to descriptive literature reviews, a systematic review reduces bias in identifying, selecting, synthesizing, and summarizing diverse research. A systematic review not only summarizes the findings of previous research but also clarifies the discrepancies across studies.

\section{Literature Research}

The Scopus database was used in this research to collect as much related literature as feasible, both locally and internationally. In order to fulfill the aim of creating a complete portrait of the products quality research today, related articles in English were included in the examination of different research trends, goods quality, customer trust and commitment, and the rest of the globe. The Scopus data store, which has been widely utilized as a data source since 2009, provides extensive coverage of over 51 articles and assures the quality of the literature by utilizing widely accepted citation indexing. Magazines are covered in the sections "Business, management, and accounting," "Computer science," "Social science," and "Multidisciplinary," which also highlight potentially important new journals that are not yet included in citation indexes.

The keywords utilized to search the papers in e-marketing were social media and online shopping, digital marketing and effectiveness, social media and digital marketing, online shopping and effectiveness, and digital marketing and conventional marketing. The article sample selection period lasted from the beginning until the present.

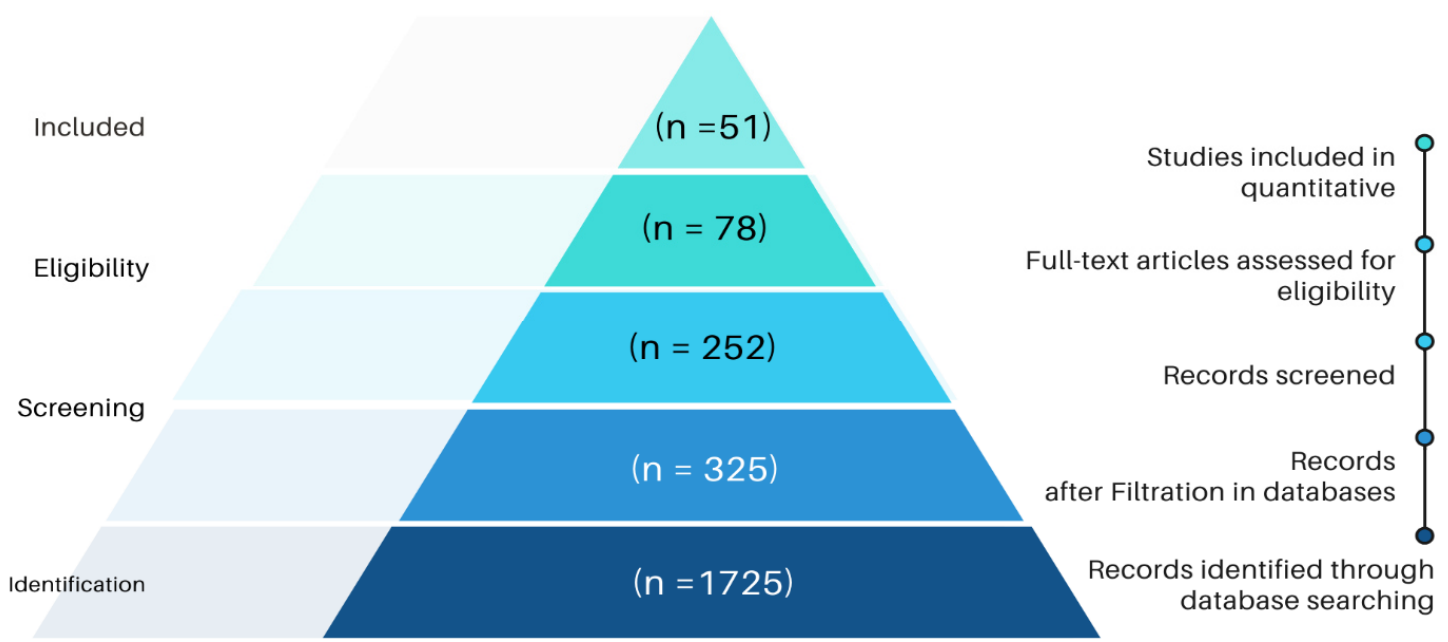

Figure 1: PRISMA statement 2015 


\section{Quality Assessment:}

The publication incorporates original papers as well as review articles. Duplication of articles in the review should be avoided. To further filter down the data, abstracts and conclusions were reviewed. The references referenced in the selected publications and the articles mentioning our sampling papers were also examined.

\section{Eligibility and Inclusion Criteria:}

Among the identified works of literature, articles were subjected to a more stringent and precise selection process based on the following criteria: Articles written in English were picked if they have been published in journals to ensure the high quality of the papers chosen. After the extraordinary expansion in Internet marketing, this article examines the marketing literature on e-marketing. The majority of the research presented quantitative data, but there were also several publications with high-quality qualitative analyses. The research also included review papers as a category. Duplicate research from various publications was eliminated, as were several studies that were irrelevant.

\section{Qualitative Synthesis Included:}

The method was divided into two parts following the selection of the 119 papers. The data was initially entered into Microsoft Excel to analyze product quality literature in marketing, including online shopping, online marketing, and internet marketing. The second step involved doing an in-depth content analysis to identify and analyze the significant research streams and report on the state of the art of research in various fields and highlight potential difficulties and topics for future research. Content analysis is a systematic method to document and text analysis that aims to characterize and quantify the evident content of communication in predetermined categories, allowing for repeatable and accurate conclusions from texts.

\section{Results}

Descriptive Analysis

Figure 2 depicts the progress of numerous e-marketing publications over a year. Due to the restricted availability of the internet, research articles on the issue of e-marketing were scarce. There was very little literature on product quality, customer happiness, and commitment. Between 2000 and 2021, research in this field has gradually increased, reaching a high in 2019. It should be emphasized that the majority of research publications were published in recent years, namely from 2007 to 2021. That pattern demonstrates that the study of emarketing from a strategic viewpoint has grown significantly over time. The goal is to develop ways to incorporate e-marketing into as many sectors as possible. The influence of digitalizing the economy has been felt in several parts of society.

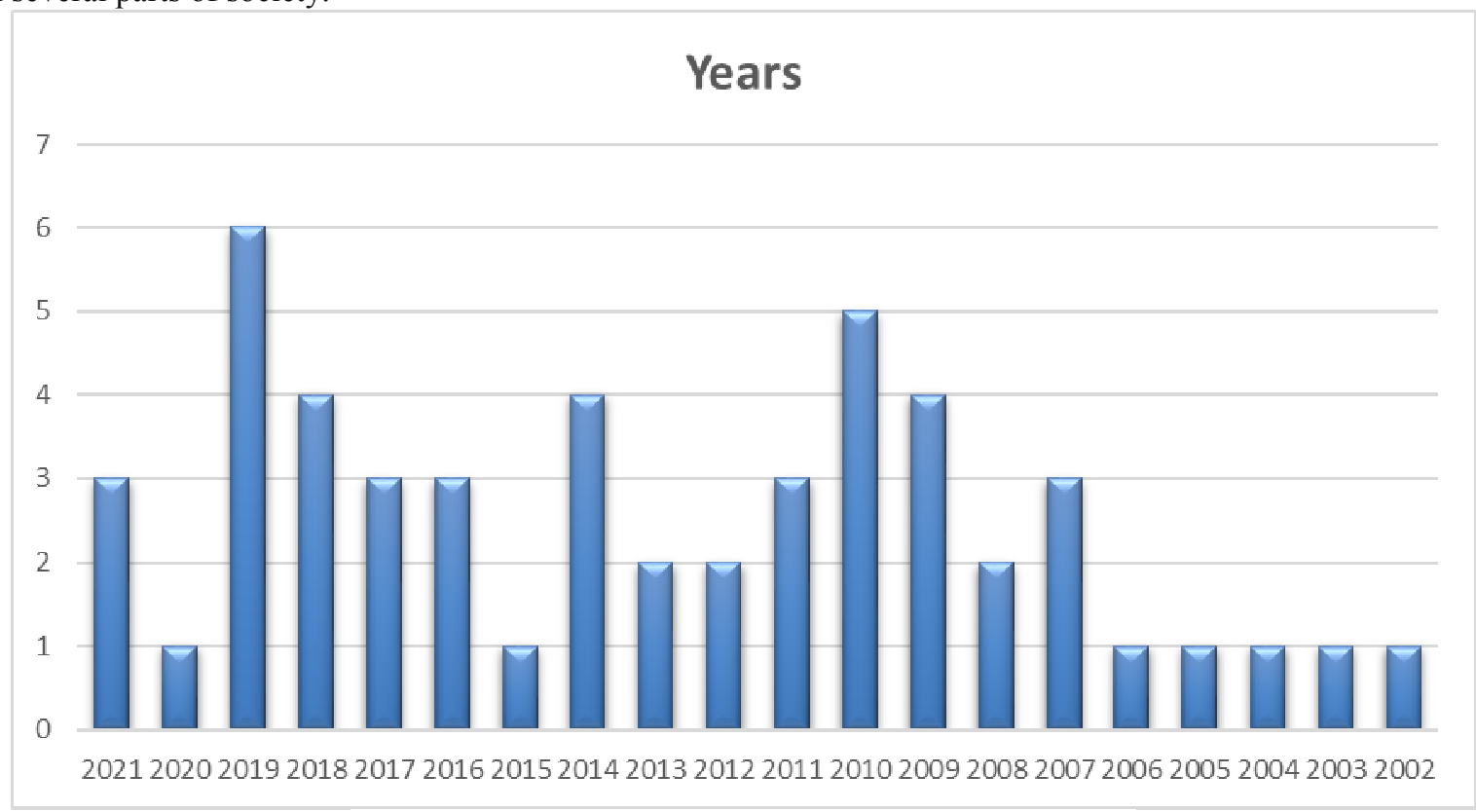

Figure 2: distribution of literature in year base publication

In figure 3, the subject Base research is listed in the Scopus database. Computer Science research included 28 percent of the research. On the topic of Business, Management, and Accounting, 27\% published research. The database results revealed that the bulk of research is focused on two topics, with a high publication ratio in both domains. Social science has $23 \%$ percent of published research, which puts it in third place. With 11 percent of published research on Scopus, the engineering subject ranks fourth. The percentages in the other areas are displayed in figure 3 below. 


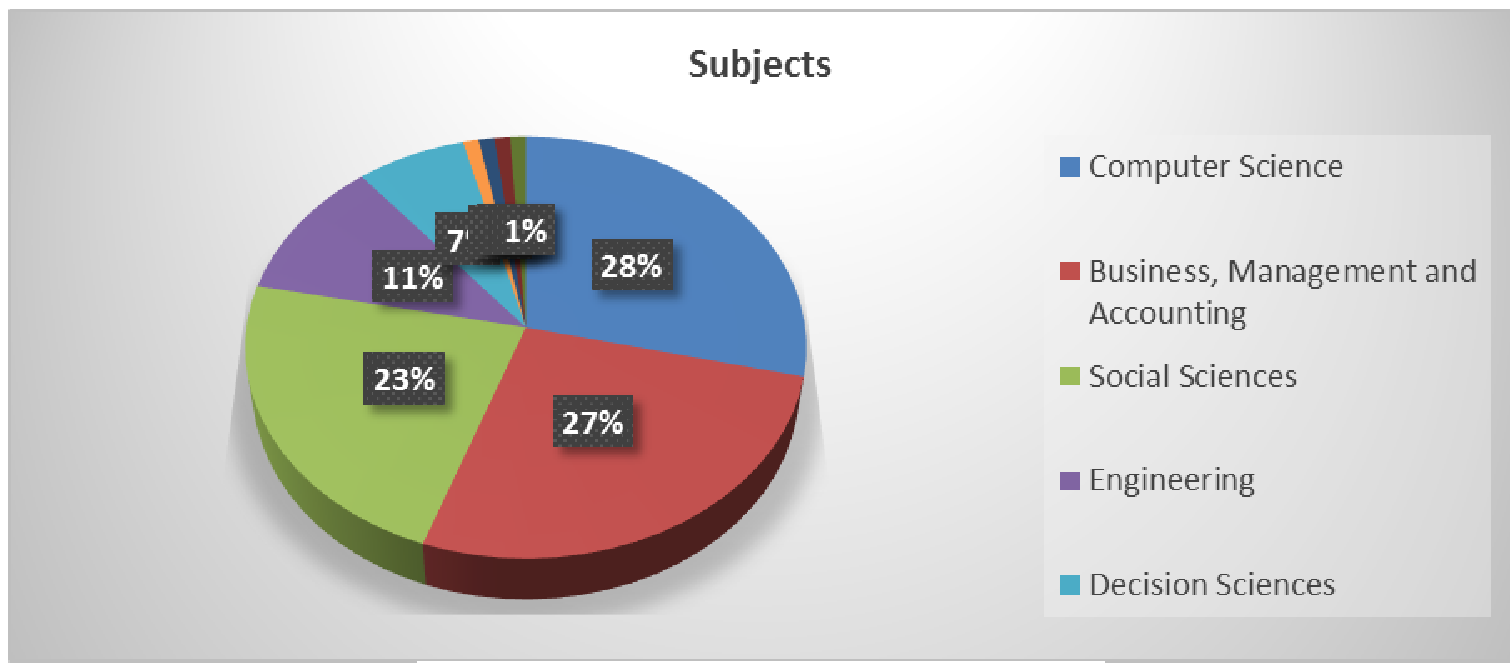

Figure 3: distribution of literature on subject base

Furthermore, the journals that published the most articles on e-marketing are reporting in Table 1. International Journal of Recent Technology and Engineering was at the top of the list with four articles and 32\% citations. Computers And Education contributed three articles with 18\% citations, and the British Journal of Educational Technology contributes two articles and 34 citations. The rest of the list is also shown in Table 1.

Table 1: source title and an average of citations

\begin{tabular}{|c|c|c|c|}
\hline SOURCE TITLE & Numbers & Citations & Average \\
\hline International Journal of Recent Technology and Engineering & 4 & 134 & $32 \%$ \\
\hline Computers And Education & 3 & 76 & $18 \%$ \\
\hline British Journal of Educational Technology & 2 & 34 & $8 \%$ \\
\hline Information And Management & 2 & 36 & $9 \%$ \\
\hline Wit Transactions on Information and Communication Technologies & 2 & 35 & $8 \%$ \\
\hline ACM Computing Surveys & 1 & 23 & $6 \%$ \\
\hline Advances In Intelligent Systems and Computing & 1 & 22 & $5 \%$ \\
\hline Applied Soft Computing Journal & 1 & 22 & $5 \%$ \\
\hline Business Horizons & 1 & 12 & $3 \%$ \\
\hline Campus Wide Information Systems & 1 & 13 & $3 \%$ \\
\hline Computers And Industrial Engineering & 1 & 9 & $2 \%$ \\
\hline
\end{tabular}

E-marketing is slowly gaining attraction in customers, and researchers are paying close attention to how this e-marketing might help improve customer satisfaction and commitment. Various researchers used the emarketing approach to improve process efficiency, and ongoing research evaluates its efficacy. We identify the most general keywords used in the research; we used the keywords customer satisfaction, usefulness, brand equity, and commitment. At the time of the literature review phase 1, a VOS viewer was used to find the number of co-occurrence terms. Fifty-one studies in the keywords; additionally, these records were used to recognize the literature classifications from these keywords, as figure 4 shows. 


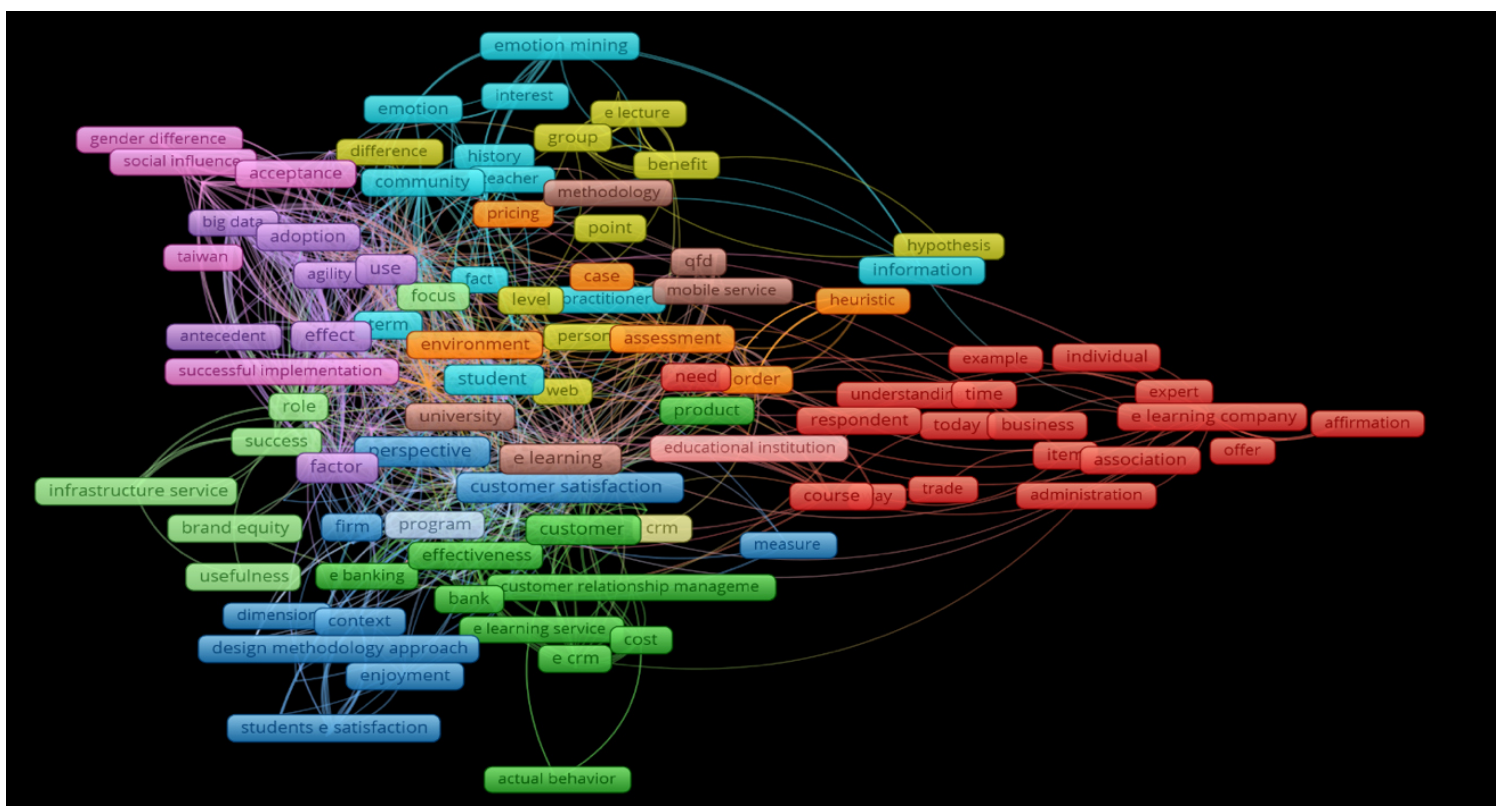

Figure 4: number of co-occurrence terms

In terms of consumer happiness, e-marketing services are continually improving, and academics are closely monitoring these changes as they occur. Various online technologies are employed during the marketing time; the current study evaluates the efficiency of e-marketing services. The published literature and researcher perspectives on commitment productivity adaptability in online services are led by further classification of literature. To identify the most prevalent terms used in the research, we utilized the keywords e-marketing, commitment, customer happiness, and customer loyalty. As stated above, there were 51 studies contained in the keywords at literature review phase 1; in addition, these records were used to recognize the literature classifications from these keywords, as Table 2 shows.

Table 2: Keyword occurrences occurrence percentage, and relevance score

\begin{tabular}{|c|c|c|}
\hline occurrences & relevance score & Percentage \\
\hline advantage & 6 & 0.2041 \\
\hline advertising & 3 & 0.9319 \\
\hline attitude & 6 & 0.9484 \\
\hline author & 3 & 0.9559 \\
\hline bank & 4 & 1.3187 \\
\hline business & 8 & 1.0057 \\
\hline cause & 3 & 1.1472 \\
\hline challenge & 5 & 1.3045 \\
\hline characteristic & 7 & 0.5167 \\
\hline circumstance & 4 & 0.4659 \\
\hline cloud computing & 3 & 1.3141 \\
\hline community & 6 & 0.7863 \\
\hline conference & 6 & 1.0723 \\
\hline cost & 7 & 0.796 \\
\hline course & 3 & 1.1771 \\
\hline CRM & 3 & 1.9026 \\
\hline customer & 15 & 0.5803 \\
\hline customer relationship management & 3 & 1.9026 \\
\hline customer satisfaction & 19 & 0.4532 \\
\hline database & 4 & 0.9198 \\
\hline decision & 5 & 0.3462 \\
\hline design methodology approach & 6 & 0.9506 \\
\hline e-learning & 16 & 1.0552 \\
\hline e-learning company & 4 & 0.4101 \\
\hline ease & 4 & 1.8119 \\
\hline effort & 4 & 0.5544 \\
\hline electronic learning & 3 & 1.5528 \\
\hline
\end{tabular}




\begin{tabular}{|c|c|c|}
\hline occurrences & relevance score & Percentage \\
\hline empirical analysis & 3 & 0.7817 \\
\hline empirical study & 4 & 1.0205 \\
\hline evidence & 4 & 0.555 \\
\hline evolution & 3 & 1.2988 \\
\hline example & 4 & 0.949 \\
\hline expectation & 4 & 1.2402 \\
\hline governance & 3 & 1.3141 \\
\hline idea & 3 & 1.2292 \\
\hline importance & 6 & 0.8785 \\
\hline improvement & 7 & 0.8509 \\
\hline individual & 4 & 1.1511 \\
\hline innovation & 3 & 1.3141 \\
\hline integration & 4 & 0.6308 \\
\hline internet & 5 & 0.508 \\
\hline item & 4 & 1.1344 \\
\hline key element & 4 & 1.5909 \\
\hline knowledge management & 5 & 0.7072 \\
\hline lecturer & 3 & 0.4804 \\
\hline level & 6 & 0.908 \\
\hline need & 11 & 0.7815 \\
\hline network & 7 & 0.582 \\
\hline neural network & 3 & 1.4208 \\
\hline new approach & 3 & 1.0518 \\
\hline number & 4 & 0.8763 \\
\hline offer & 3 & 1.5275 \\
\hline optimization & 4 & 1.0901 \\
\hline order & 7 & 1.2199 \\
\hline originality value & 6 & 0.9506 \\
\hline part & 5 & 1.2333 \\
\hline platform & 6 & 0.7651 \\
\hline practical implication & 3 & 1.3219 \\
\hline proceeding & 7 & 0.9337 \\
\hline program & 5 & 0.8952 \\
\hline qfd & 3 & 0.709 \\
\hline questionnaire & 3 & 1.1425 \\
\hline reliability & 4 & 1.5564 \\
\hline respect & 3 & 0.6867 \\
\hline respondent & 7 & 1.2311 \\
\hline risk assessment & 3 & 1.3141 \\
\hline risk management & 4 & 1.1242 \\
\hline role & 12 & 0.4519 \\
\hline sample & 8 & 1.4286 \\
\hline service quality & 8 & 0.5199 \\
\hline software & 5 & 0.7509 \\
\hline special focus & 5 & 1.0626 \\
\hline student & 14 & 0.8515 \\
\hline successful implementation & 3 & 0.7007 \\
\hline survey & 13 & 0.6015 \\
\hline teaching & 3 & 1.2797 \\
\hline technology acceptance model & 3 & 1.8627 \\
\hline term & 6 & 0.5973 \\
\hline thing & 3 & 1.0165 \\
\hline time & 9 & 0.3171 \\
\hline today & 5 & 1.2732 \\
\hline topic & 8 & 0.7755 \\
\hline
\end{tabular}




\begin{tabular}{|c|c|c|}
\hline occurrences & relevance score & Percentage \\
\hline trend & 3 & 1.3141 \\
\hline usefulness & 4 & 1.6404 \\
\hline user & 9 & 1.1072 \\
\hline validity & 3 & 1.6147 \\
\hline volume & 3 & 1.2797 \\
\hline web & 3 & 0.5457 \\
\hline
\end{tabular}

\section{Classification of Literature:}

Today's consumers want businesses to interact with them in several ways, delivering the best possible experience while also indicating that they have similar interests. They want to buy from companies that understand who they are, what they require, and how to address their issues (Akhtar et al., 2021). While a personalized experience may be beneficial, other online tools can build consumer trust and connections. Many quality labels have been created to assure product quality because it is one of the most significant factors affecting customer purchases (Mustapha et al., 2021). Furthermore, customers can quickly recognize high-quality goods and make better purchase decisions, implying that superior packaging and services may contribute to the perception of high quality. A high degree of comparable quality may be directly linked to customer cognitive commitment (Savage et al., 2013b). A similar trend may be seen in the emotional dimension of commitment. A high level of transactional quality provides regular positive reinforcement for making the right option, which leads to emotional bonds (Arli et al., 2017).

However, Overall features include fulfilling the customer's social requirements associated with productrelated transactions, which is more significant and valid, especially in person-to-person contacts (Cook et al., 2015). Customer loyalty not only ensures repeat purchases and positive publicity with more excellent reliability, but it also leads to a slew of other significant benefits such as cross-buying intentions, exclusive and prioritybased preference for the company and its products/services, increased share of wallet, and all of which give the company a competitive advantage. E-marketing has become one of the most critical factors in maintaining a company's competitive edge (Dinçer et al., 2019).

Although, Customers began purchasing through e-commerce rather than physical businesses. Physical companies have tried to acquire a competitive edge by interacting with clients through e-commerce. When a consumer is devoted to a product, they may shift to internet marketing. Customer reviews not only inform future customers that a brand is similar to them, but they can also assist in exhibit quality (Wehrli et al., 2018). Positive reviews are regarded as a stronger predictor of product quality by consumers aged 18 to 64, and online businesses have minimal entry barriers, allowing rivals to quickly enter the market (Qiao et al., 2018). When transferring from one online shop to another, customers enjoy lower switching expenses. In both physical and online businesses, consumer shopping experiences impact future customer behavior, such as repurchase intent, store revisits intention, and word of mouth (Barbato \& Di Natale, 2019). According to (Qureshi, Khan, Ahmad Hassan Gillani, et al., 2020), electronic marketing operations have gotten much attention in recent years due to the rapid growth of the internet market. Many businesses increased client loyalty by enhancing their electronic services (e-service quality), but the benefits need to be studied further (Lazzarini \& Musacchio, 2020). Table 3 is showing the details of the literature output.

Table 3: context, focus, segment, and findings of the literature

\begin{tabular}{|l|l|l|l|l|}
\hline Context & Focus & Segment & Methodology & Findings \\
\hline online advertising & $\begin{array}{l}\text { low involvement } \\
\text { product (mineral } \\
\text { water) and one of } \\
\text { high involvement } \\
\text { product }\end{array}$ & $\begin{array}{l}\text { advertise } \\
\text { ment } \\
\text { industry }\end{array}$ & regression & $\begin{array}{l}\text { Managers in the advertising sector, } \\
\text { particularly in the internet advertising } \\
\text { market, might benefit from the } \\
\text { conclusions of this study. It gives the } \\
\text { marketing manager helpful information } \\
\text { for creating an online commercial that } \\
\text { will become viral by utilizing digital } \\
\text { media to its full potential. }\end{array}$ \\
\hline mobile shopping & mobile shopping & $\begin{array}{l}\text { mobile } \\
\text { shopping }\end{array}$ & $\begin{array}{l}\text { structural } \\
\text { equation } \\
\text { model }\end{array}$ & $\begin{array}{l}\text { A key conclusion that varies from prior } \\
\text { studies is that the connection between } \\
\text { perceived norms and behavioral } \\
\text { intention to utilize M-shopping was not } \\
\text { significant, contrary to earlier findings. }\end{array}$ \\
\hline $\begin{array}{l}\text { Millennial } \\
\text { generation }\end{array}$ & $\begin{array}{l}\text { Millennials on the } \\
\text { world economy }\end{array}$ & changes in ethical beliefs & $\begin{array}{l}\text { The results show that consumer ethics } \\
\text { remain constant across time. }\end{array}$ \\
\hline
\end{tabular}




\begin{tabular}{|c|c|c|c|c|}
\hline $\begin{array}{l}\text { financial service } \\
\text { sector }\end{array}$ & $\begin{array}{l}\text { banking } \\
\text { performance }\end{array}$ & $\begin{array}{l}\text { digital } \\
\text { banking }\end{array}$ & $\begin{array}{l}\text { confirmatory } \\
\text { factor analysis } \\
\text { and structural } \\
\text { equation } \\
\text { modeling. }\end{array}$ & $\begin{array}{l}\text { Through the mediation of business } \\
\text { strategies, the main success elements of } \\
\text { social CRM and relationship marketing } \\
\text { orientation were indirect impacts on } \\
\text { banking performance effectiveness. }\end{array}$ \\
\hline $\begin{array}{l}\text { digital } \\
\text { transformation }\end{array}$ & SMEs & SMEs & $\begin{array}{l}\text { random } \\
\text { sampling }\end{array}$ & $\begin{array}{l}\text { The measurement findings indicate that } \\
\text { the created measurement model may be } \\
\text { too complex for the firms under } \\
\text { examination. }\end{array}$ \\
\hline digital piracy & $\begin{array}{l}\text { moral equity, } \\
\text { relativism, and } \\
\text { attitude towards } \\
\text { digital piracy } \\
\text { behavior }\end{array}$ & \multicolumn{2}{|c|}{ digital piracy } & $\begin{array}{l}\text { Few studies are looking at the variables } \\
\text { that influence the purchase of pirated } \\
\text { software and CDs in developing } \\
\text { countries, particularly Indonesia, the } \\
\text { world's fourth most populous country } \\
\text { and one of the largest marketplaces for } \\
\text { counterfeit goods. }\end{array}$ \\
\hline digital piracy & $\begin{array}{l}\text { impact of young } \\
\text { consumer's } \\
\text { religiousness on } \\
\text { their attitude and } \\
\text { intention }\end{array}$ & \multicolumn{2}{|c|}{$\begin{array}{l}\text { religiosity among young } \\
\text { consumers }\end{array}$} & $\begin{array}{l}\text { The findings of this study will have } \\
\text { significant consequences for } \\
\text { management, particularly religious } \\
\text { leaders, in terms of how to prevent } \\
\text { digital piracy. }\end{array}$ \\
\hline digital piracy & $\begin{array}{l}\text { determinants of } \\
\text { attitude towards } \\
\text { digital piracy }\end{array}$ & \multicolumn{2}{|c|}{ digital piracy } & $\begin{array}{l}\text { Affective beliefs, perceived relevance of } \\
\text { the digital piracy issue, and } \\
\text { Machiavellianism are predictors of } \\
\text { female customers' attitudes about digital } \\
\text { piracy. }\end{array}$ \\
\hline digital media & $\begin{array}{l}\text { Interactive Digital } \\
\text { Media }\end{array}$ & \multicolumn{2}{|c|}{ digital media } & $\begin{array}{l}\text { We propose a particularly well-suited } \\
\text { method to dynamic scenario planning, } \\
\text { which necessitates a periodic review of } \\
\text { key assumptions and market } \\
\text { circumstances. }\end{array}$ \\
\hline digital marketing & $\begin{array}{l}\text { histogram } \\
\text { equalization }\end{array}$ & \multicolumn{2}{|c|}{ visual content } & $\begin{array}{l}\text { OCR preprocessing was used to perform } \\
\text { histogram equalization successfully. }\end{array}$ \\
\hline digital maps & $\begin{array}{l}\text { intersections and } \\
\text { traffic lights }\end{array}$ & \multicolumn{2}{|c|}{ traffic light signal } & $\begin{array}{l}\text { an improvement in the accuracy up to } \\
5.2 \% \text {, dependent on the test conditions. }\end{array}$ \\
\hline digital ecosystem & $3 g$ and $4 g$ & \multicolumn{2}{|c|}{ mobile network services } & $\begin{array}{l}\text { The data also point to a shift in the way } \\
\text { people perceive service experience while } \\
\text { using } 4 \mathrm{G} \text { applications. }\end{array}$ \\
\hline $\begin{array}{l}\text { digital } \\
\text { competence }\end{array}$ & $\begin{array}{l}\text { Developing IT } \\
\text { workforces }\end{array}$ & $\begin{array}{l}\text { IT } \\
\text { industry }\end{array}$ & $\begin{array}{l}\text { Descriptive } \\
\text { statistics, } \\
\text { correlation, } \\
\text { and regression } \\
\text { analysis }\end{array}$ & $\begin{array}{l}\text { Universities may utilize the findings of } \\
\text { this empirical study to promote } \\
\text { curriculum change to fulfill industry } \\
\text { requirements and students who need to } \\
\text { be aware of employers' demands to } \\
\text { prepare for IT employment. }\end{array}$ \\
\hline $\begin{array}{l}\text { digital } \\
\text { information }\end{array}$ & $\begin{array}{l}\text { purchase decision } \\
\text { in goods }\end{array}$ & goods & $\begin{array}{l}\text { causal } \\
\text { relationship }\end{array}$ & $\begin{array}{l}\text { As a result, content producers should } \\
\text { invest in techniques that assist customers } \\
\text { in understanding how information items } \\
\text { fit into their preferences. }\end{array}$ \\
\hline $\begin{array}{l}\text { Google and } \\
\text { Advanced Land } \\
\text { Observation } \\
\text { Satellite images }\end{array}$ & health & \multicolumn{2}{|c|}{ health issues } & $\begin{array}{l}\text { As a result, using scalable Digital Earth } \\
\text { technologies to monitor health concerns } \\
\text { might open up new avenues for } \\
\text { sustaining a healthy and sustainable } \\
\text { society in the future. }\end{array}$ \\
\hline $\begin{array}{l}\text { digital wireless } \\
\text { phones }\end{array}$ & \multicolumn{3}{|c|}{$\begin{array}{l}\text { Determining information technology (IT) } \\
\text { success in a market }\end{array}$} & $\begin{array}{l}\text { The findings show that standards' } \\
\text { presence and impact are essential in } \\
\text { promoting takeoff and penetration } \\
\text { expansion. }\end{array}$ \\
\hline
\end{tabular}




\begin{tabular}{|l|l|l|l|l|}
\hline $\begin{array}{l}\text { digital creative } \\
\text { industry }\end{array}$ & $\begin{array}{l}\text { sustained } \\
\text { high } \\
\text { performance }\end{array}$ & $\begin{array}{l}\text { digital creative } \\
\text { industry }\end{array}$ & $\begin{array}{l}\text { structural } \\
\text { equation } \\
\text { model }\end{array}$ & $\begin{array}{l}\text { This research looked at dynamic } \\
\text { capability as an emerging business } \\
\text { paradigm that drives high performance } \\
\text { in a quickly changing environment. }\end{array}$ \\
\hline
\end{tabular}

Electronic marketing, without a doubt, has a positive impact on sales and loyalty. Instead, it may be leveraged to improve consumer loyalty and corporate growth (Odhiambo, 2012). Traditional marketing methods include making a TV commercial, placing an ad in a magazine, or even broadcasting a commercial on the radio, which require large financial investments that many businesses may not bear (Tweneboah-Koduah et al., 2017). According to (Iqbal et al., 2013), regulate the ad's activation or deactivation and the target age range, all while determining the financial charges. Its significance grows in tandem with the number of the internet user. In addition, the fierce competition to gain market share by assisting businesses with plans, strategies, and marketing ideas through the integrated marketing mix, e-marketing has emerged as one of the most critical dimensions (Hung et al., 2013). Strategic gains in modern marketing, where it is impossible to reach anyone at any time without permission using any time, place, or language (Tchoffa et al., 2016).

Customer loyalty is more difficult to build online than it is offline. Customers may be more inclined to retain and extend their relationship with a supplier if a website offers excellent information, system, and service quality (Ismail et al., 2021). This project proposes to create and test an evaluation model. The impact of product quality, customer trust, and company commitment on e-marketing and the link between product quality and customer trust and how customer trust influences relationship depth and breadth more than customer satisfaction (Mustapha et al., 2021).

\section{Conclusion}

In the highly competitive world of e-commerce, customer e-loyalty is a critical problem-E-satisfaction, e-trust, and e-service quality all impact e-loyalty. Customers are resistant to purchasing through e-marketing; therefore, persuading them to do so is challenging. Before making a purchase, some buyers prefer to read much information (Hishan et al., 2021). For the initial data collection in the search bar, e-marketing was used. Then, for the following stage, only related published articles and reviews were picked. A methodical strategy was utilized to choose the literature in order to avoid duplication and superfluous records. The Preferred Reporting Items for Systematic Reviews and Meta-Analyses (PRISMA) statement specifies which data should be included and excluded. The Scopus database was used to compile the items above. The data is finally combined on a single Microsoft Excel sheet, and the extraction method is the same. The current study organizes the literature on e-marketing, consumer satisfaction, and loyalty.

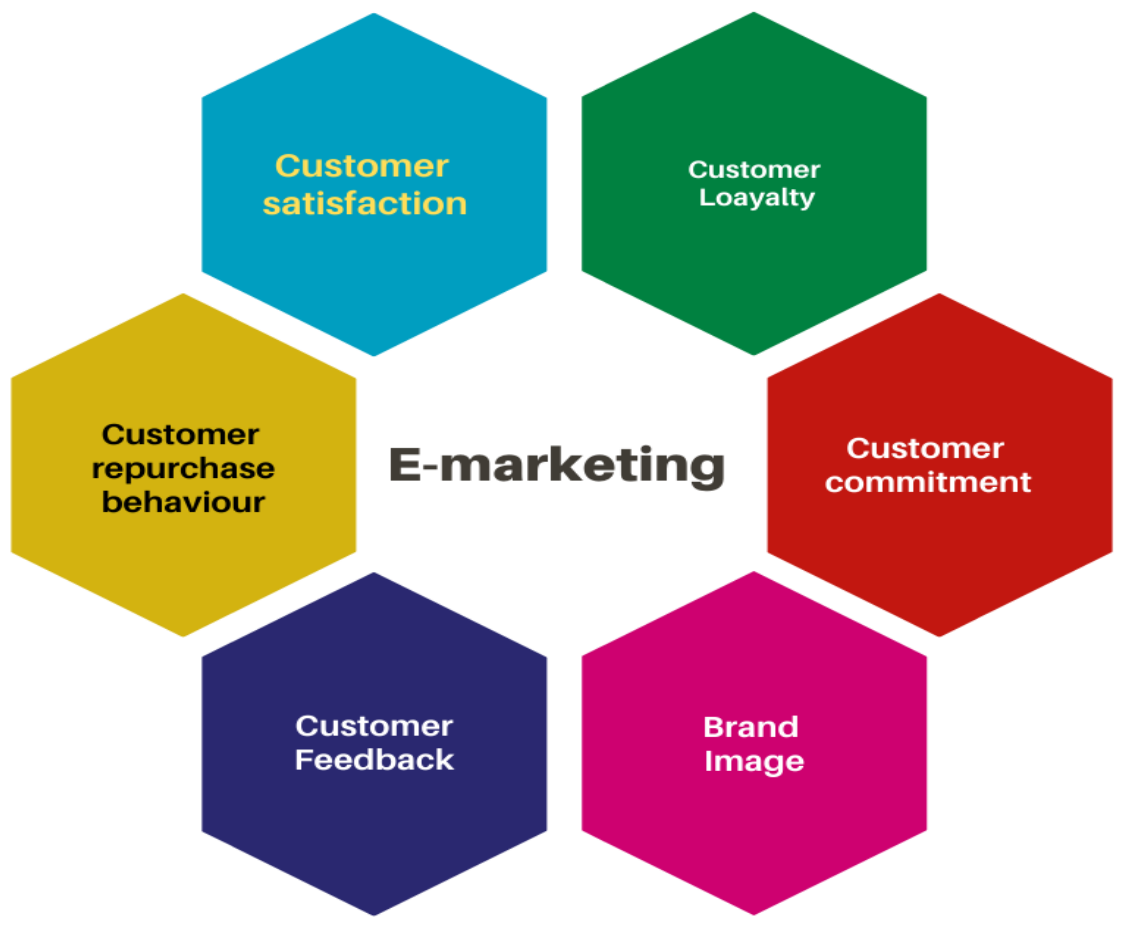

Figure 5: literature outcomes of the r-marketing

The researchers' findings are extensively explored in connection to services and educational institutions. 
The author's keywords and the VOS viewer co-occurrence findings are similar for the classification of the published literature. This study aims to show how to utilize VOS viewer to do data mining for accurate literature assessment. In addition, co-occurrence of keywords extraction is used in the literature search for e-marketing. Some businesses give customers product samples in order to enhance their trust and loyalty to the brand. The customer expressed loyalty is described as a good impression of an e-service provider's online website that encourages recurring purchases. Several studies have investigated the history of good online services regarding navigation, visual appeal, speed, accessibility, content customization, and dependability. Users might build loyalty if their previous interactions with their operators have been positive.

\section{References}

Akhtar, N., Khan, N., Mahroof Khan, M., Ashraf, S., Hashmi, M. S., Khan, M. M., \& Hishan, S. S. (2021). PostCOVID 19 Tourism: Will Digital Tourism Replace Mass Tourism? Sustainability, 13(10), 5352. https://doi.org/10.3390/su13105352

Arli, D., Tjiptono, F., Lasmono, H., \& Anandya, D. (2017). Do consumer ethics and consumer religiousness evolve across time? Insights from Millennials in Indonesia. Young Consumers, 18(4), 329-347. https://doi.org/10.1108/YC-05-2017-00697

Barbato, S., \& Di Natale, L. (2019). From chat therapy to virtual reality (VR): The case of Indigo-Digital Psychology. In Virtual and augmented reality in mental health treatment. (pp. 199-220). https://www.igiglobal.com/chapter/from-chat-therapy-to-virtual-reality-vr/215830

Bt Jaafar, J., Najieha Binti Ishak, A., Bin Hassan, S., Firdaus Bin Adrutdin, K., \& Imran Qureshi, M. (2020). A Study of Customer Satisfaction with Planning Movement of Goods during Disaster Aid Programs: A Case Study of Flood-Hit in Segamat, Johor. In Journal of Environmental Treatment Techniques (Vol. 0202, Issue 1). http://www.jett.dormaj.com

Cook, B. I., Ault, T. R., \& Smerdon, J. E. (2015). Unprecedented 21st-century drought risk in the American Southwest and Central Plains. In Science Advances (Vol. 1, Issue 1). https://doi.org/10.1126/sciadv.1400082

Dinçer, H., Yüksel, S., \& Martínez, L. (2019). Balanced scorecard-based analysis about European energy investment policies: A hybrid hesitant fuzzy decision-making approach with Quality Function Deployment. Expert Systems with Applications, 115, 152-171. https://doi.org/10.1016/j.eswa.2018.07.072

Hellman, G. P., \& Thompson, F. W. (2017). Physicalism: Ontology, determination, and reduction. In Supervenience (pp. 1-14). Taylor and Francis Inc. https://doi.org/10.4324/9781315242071-1

Hishan, S. S., Qureshi, M. I., Khan, N., Ramakrishnan, S., Jaiprakash, H., \& Vaicondam, Y. (2021). Impact of COVID-19 pandemic on sustainable development goals: What we learn from the past and where we are heading? Studies of Applied Economics, 39(3).

Hung, C. Y., Lee, W. Y., \& Wang, D. S. (2013). Strategic foresight using a modified Delphi with end-user participation: A case study of the iPad's impact on Taiwan's PC ecosystem. Technological Forecasting and Social Change, 80(3), 485-497. https://doi.org/10.1016/j.techfore.2012.08.008

Iqbal, M. F., Riaz Khan, M., \& Malik, A. H. (2013). Land-use change detection in the limestone exploitation area of Margalla Hills National Park (MHNP), Islamabad, Pakistan using geo-spatial techniques. Journal of Himalayan Earth Sciences, 46(1), 89-98. http://nceg.uop.edu.pk/GeologicalBulletin/Vol-46(1)2013/Vol-46(1)-2013-Paper10.pdf

Ismail, F., Imran, A., Khan, N., \& Qureshi, M. I. (2021). Past, present, and future of ecotourism, a systematic literature review from last decade. Studies of Applied Economics, 39(4).

Khan, N., Qureshi, M. I., Mustapha, I., Harasis, A. A., \& Ashfaq, M. (2020). The Digital Marketing Past, Present, and Future in Malaysia. Journal of Computational and Theoretical Nanoscience, 17(2), 583-595. https://doi.org/10.1166/jetn.2020.8732

Khan, N., Qureshi, M. I., Mustapha, I., Irum, S., \& Arshad, R. N. (2020). A systematic literature review paper on online medical mobile applications in Malaysia. International Journal of Online and Biomedical Engineering, 16(1), 63-82. https://doi.org/10.3991/ijoe.v16i01.12263

Lazzarini, S. G., \& Musacchio, A. (2020). Leviathan As a Partial Cure? Opportunities and Pitfalls of Using the State-Owned Apparatus to Respond to the COVID-19 Crisis. SSRN Electronic Journal. https://doi.org/10.2139/ssrn.3562406

Mustapha, I., Van, N. T., Shahverdi, M., Qureshi, M. I., \& Khan, N. (2021). Effectiveness of Digital Technology in Education During COVID-19 Pandemic. A Bibliometric Analysis. International Journal of Interactive Mobile Technologies, 15(8), 136-154. https://doi.org/10.3991/ijim.v15i08.20415

Odhiambo, C. A. (2012). Social Media as a Tool of Marketing and Creating Brand Awareness. Business Economics and Tourism, $1-80$. https://www.theseus.fi/bitstream/handle/10024/44591/Christine.A.Odhiambo.pdf?sequence=1

Qiao, X. J., Kristoffersson, A., \& Randrup, T. B. (2018). Challenges to implementing urban sustainable 
stormwater management from a governance perspective: A literature review. In Journal of Cleaner Production (Vol. 196, pp. 943-952). Elsevier. https://doi.org/10.1016/j.jclepro.2018.06.049

Qureshi, M. I., Khan, N., Ahmad Hassan Gillani, S. M., \& Raza, H. (2020). A systematic review of the past decade of mobile learning: What we learned and where to go. International Journal of Interactive Mobile Technologies, 14(6), 67-81. https://doi.org/10.3991/IJIM.V14I06.13479

Qureshi, M. I., Khan, N., Qayyum, S., Malik, S., Sanil, H. S., \& Ramayah, T. (2020). Classifications of sustainable manufacturing practices in ASEAN region: A systematic review and bibliometric analysis of the past decade of research. In Sustainability (Switzerland) (Vol. 12, Issue 21, pp. 1-19). MDPI AG. https://doi.org/10.3390/su12218950

Raza, H., Hassan Gillani, S. M. A., Ahmad, H., Qureshi, M. I., \& Khan, N. (2021). Impact Of Micro And Macro Dynamics On Share Price Of Non-Financial Listed Firms In Textile Sector Of Pakistan. Journal of Contemporary Issues in Business and Government, 27(1), 59-70.

Savage, M., Devine, F., Cunningham, N., Taylor, M., Li, Y., Hjellbrekke, J., Le Roux, B., Friedman, S., \& Miles, A. (2013a). A New Model of Social Class? Findings from the BBC's Great British Class Survey Experiment. Sociology, 47(2), 219-250. https://doi.org/10.1177/0038038513481128

Savage, M., Devine, F., Cunningham, N., Taylor, M., Li, Y., Hjellbrekke, J., Le Roux, B., Friedman, S., \& Miles, A. (2013b). A New Model of Social Class? Findings from the BBC's Great British Class Survey Experiment. Sociology, 47(2), 219-250. https://doi.org/10.1177/0038038513481128

Sreedevi, P., Sudarsana Reddy, P., Rao, K. V. S. N., \& Chamkha, A. J. (2017). Heat and mass transfer flow over a vertical cone through a nanofluid saturated porous medium under convective boundary condition suction/injection. Journal of Nanofluids, 6(3), 478-486. https://doi.org/10.1166/jon.2017.1349

Tchoffa, D., Figay, N., Ghodous, P., Exposito, E., Kermad, L., Vosgien, T., \& El Mhamedi, A. (2016). Digital factory system for dynamic manufacturing network supporting networked collaborative product development. Data and Knowledge Engineering, 105, 130-154. https://doi.org/10.1016/j.datak.2016.02.004

Tweneboah-Koduah, S., Skouby, K. E., \& Tadayoni, R. (2017). Cyber Security Threats to IoT Applications and Service Domains. Wireless Personal Communications, 95(1), 169-185. https://doi.org/10.1007/s11277017-4434-6

Wehrli, L., Saheb-Al-Zamani, M., Khanna, M., Lax, M. J., \& Anastakis, D. J. (2018). Lipomatosis of nerve: More than a distal focal disease. Plastic and Reconstructive Surgery, 142(1), 148-151. https://doi.org/10.1097/PRS.0000000000004455 